\title{
PP/EPDM Polymeric Compounds Dynamically Cured Compatibilized and Reinforced with Nanoclay
}

\author{
MIH AELA (VILSAN) NITUICA ${ }^{1,2 *}$, AURELIA MEGHEA², DANA GURAU1, MARIA DANIELA STELESCU ${ }^{1}$ \\ ${ }^{1}$ National Research and Development Institute for Textile and Leather, Division Leather and Footwear Research Institute, 93 Ion \\ Minulescu Str., 031215, Bucharest, Romania \\ 2University Politehnica of Bucharest, Faculty of Applied Chemistry and Materials Science,1 Polizu Str., 011061, Bucharest, \\ Romania
}

\begin{abstract}
This paper presents the development of dynamically cured polymer composites and nanocomposites based on plastomer - PP (polypropylene) and EPDM elastomer (ethylene-propylene-diene-terpolymer) compatibilized and reinforced with nanometric particles-MMT (montmorillonite, chemically modified layered clay) in two stages, by extrusion-granulation and mixing. Nanoparticles increase the thermal resistance of dynamically cured polymer nanocomposites. By means of compatibilization and dynamic curing, elastomer particles - EPDM are more easily dispersed in the mixture. The materials obtained were tested physicomechanically (Melt Flow Index) and morpho-structurally (FT-IR and DSC).
\end{abstract}

Key words: terpolymer rubber, polypropylene, nanoclay, dynamic vulcanization

In recent years, research has led to new advanced polymer materials, starting from existing polymers, which are mechanically and chemically processed resulting in polymer composites with advanced properties. In elastoplastic alloys, the elastomer (rubber) may be vulcanized with various crosslinking agents in order to obtain new polymer materials with superior physicomechanical characteristics and properties compared to classical polymers [1-4].

Uniroyal Chemicals Corporation was the first company that brought dynamically cured thermoplastic mixtures to the market. Dynamic vulcanizates are a category of melt mixing with thermoplastic elastomer. In 1971 W.K. Fischer [5] used for the first time the elastomer/plastomer mixture (EPDM/PP) crosslinking technique with peroxides, and in 1978 Coran and Patel [6] developed and improved this technique. Selection of the crosslinking system is very important in obtaining thermoplastic materials, since it provides them with elasticity, but also influences physicomechanical characteristics, humidity and adherence between EPDM and PP phases [7-10].

In order to obtain dynamically cured polymer composites compatibilized and reinforced with nanoparticles, elastomers (ethylene-propylene-diene-terpolymer rubber - EPDM), and plastomers (polypropylene, PP) were used. [11-15] The resulting materials were compatibilized with polypropylene-graft-maleic anhydride - PP-g-MA, crosslinked with dicumyl peroxide - DCP and reinforced with nanometric particles of chemically modified layered clay - MMT (montmorillonite) [16-20].

The paper presents technologies for developing dynamically cured polymer composites and nanocomposites by extrusion-granulation and mixing, taking samples to determine physicomechanical characteristics - melt flow index and morpho-structural characteristics (FT-IR spectrometry and Differential scanning calorimetry - DSC).

\section{Experimental part \\ Materials \\ The following materials were used in the study: \\ -Elastomer: ethylene-propylene-diene-terpolymer rubber- NORDEL IP 4760 (EPDM) from DuPont, Dow}

Elastomer, USA (specific gravity - 0.872 , Mooney viscosity - $60 \mathrm{MU}$, ethylene content $-67.5 \mathrm{wt} \%$, ethylidenenorbornene (EBN) contents - $5.0 \mathrm{wt} \%$, molecular weight distributionmedium, propylene content - $27.5 \mathrm{wt} \%)$;

-Plastomer: polypropylene Tipplen K 948(PP) from Tiszai Vegyi Kombinat RT, Hungary, (polypropylene impact copolymer, melt mass-flow rate (MFR) $\left(230^{\circ} \mathrm{C} / 2.16 \mathrm{~kg}\right)$ $45 \mathrm{~g} / 10 \mathrm{~min}$; processing (melt) temperature -190 to $240^{\circ} \mathrm{C}$ ); -Compatibilizer: polypropylene-graft-maleic anhydride (PP-g-AM)from Sigma Aldrich, Germany (specific gravity - $0.934 \mathrm{~g} / \mathrm{cm}^{3}$, average $\mathrm{Mw} \sim 9.100$ by GPC, average $\mathrm{Mn} \sim 3,900$ by GPC, maleic anhydride $8-10 \mathrm{Wt}$ );

-Nanoclay: MMT - chemically modified montmorillonite Nanoclay I.31.PS from SigmaAldrich (modified surface contains $0.5-5 w t \%$ aminopropyltriethoxysilan, $15-35 w t \%$ octadecylamine, di(tert-butylperoxyiso propyl) benzene (powder 40\% with calcium carbonate and silica);

-The vulcanizing agent: dibenzoyl peroxide Perkadox 1440B from Akzo Nobel Chemicals (density $1.60 \mathrm{~g} / \mathrm{cm}^{3}, 3.8 \%$ active oxygen content, $40 \%$ peroxide content, $\mathrm{pH} 7$ ).

\section{Nanocomposite preparation}

- Polymer composites and nanocomposites were obtained in two stages. In the first stage thermoplastic olefins elastomers were obtained based on PP/EPDM, with and without PP-g-MA by melt mixing in a TSE 35 co-rotating twin screw extruder granulator (fig. 1). Polymer composites based on PP/EPDM and PP/PP-g-MA/EPDM developed using an extruder-granulator, were made based on the following methodology: raw materials were dosed according to formulations for elasto-plastic materials presented in table 1; components were mixed manually or using a paddle mixer with plastic recipients of varying weights, taking into account the amount of component added to the mixture; polypropylene is introduced when extruder temperature has reached $150^{\circ} \mathrm{C}$ (optimal temperature for polypropylene plasticization) and 150-200 rotations/min and is mixed until it is easy to process, at these parameters the plastic material is plasticized; after PP plasticization the temperature is raised to $175^{\circ} \mathrm{C}$, the elastomer-EPDM and compatibilizer - PP-g-MA are added continuing mixing at $250-280$ rotations/minute until ingredients are dispersed and the mixture is homogenous;

\footnotetext{
* email: mihaelavilsan@yahoo.com; mihaela.nituica@icpi.ro
} 


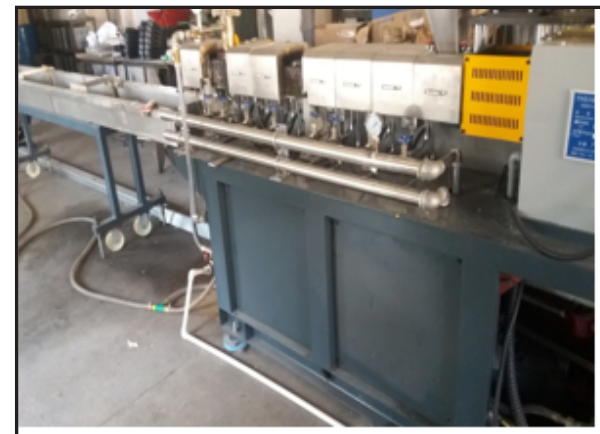

Detail - A

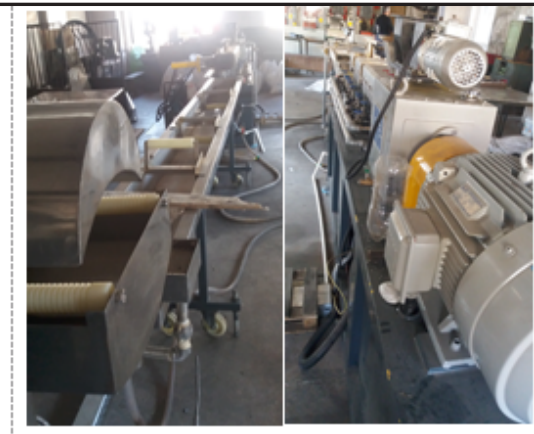

Detail - B
Fig. 1. Co-rotating twin screw extruder granulator, TSE 35 (A and $B$ extruder granulator details)

\begin{tabular}{|c|c|c|c|c|c|c|c|}
\hline \multicolumn{9}{|c|}{ Sample code } \\
\hline Material & UM & $\mathrm{M}_{3}$ & $\mathrm{M}_{31}$ & $\mathrm{M}_{315}$ & $\mathrm{M}_{315} \mathrm{M}_{1}$ & $\mathrm{M}_{315} \mathrm{M}_{2}$ & $\mathrm{M}_{315} \mathrm{M}_{3}$ \\
\hline PP(phr) & $\%$ & 50 & 50 & 50 & 50 & 50 & 50 \\
\hline EPDM(phr) & $\%$ & 50 & 50 & 50 & 50 & 50 & 50 \\
\hline PP-g-MA(phr) & $\%$ & - & 5 & 5 & 5 & 5 & 5 \\
\hline MMT (phr) & $\%$ & - & - & - & 1 & 3 & 7 \\
\hline PD (phr) & $\%$ & - & - & 3 & 3 & 3 & 3 \\
\hline
\end{tabular}

Table 1

FORMULATIONS the thread is cooled and dried, then inserted in the grinder and the granule length is set; the homogenous mixture is obtained in the form of cylindrical granules of $3 \mathrm{~mm} \times 3 \mathrm{~mm}$.

Figure 2 shows polymer composite mixtures obtained in granular form, made using the extruder granulator, and used in obtaining dynamically cured polymer nanocomposites.

-Optimal work parameters on the extruder-granulator, set after testing, are presented in table 2.

-The second stage consists in processing granules obtained in a Plasti-Corder Brabender Mixer 350 E (fig. 3), in order to obtain dynamically crosslinked nanocomposites.

Nanocomposites are obtained by introducing PP/EPDM/ PP-g-MA granules at the temperature of $165^{\circ} \mathrm{C}$ (area 1)/ $175^{\circ} \mathrm{C}$ (area 2$) / 175^{\circ} \mathrm{C}$ (area 3 ), with the maximum rotation speed of $280 \mathrm{rot} / \mathrm{min}$, mixing time $3 \mathrm{~min}$. MMT and DCP are added and mixing continues for $3 \mathrm{~min}$.
-Samples for characterization are obtained using an electrically heated press, TP 600 Fortijme Grotness, Netherlands, by compression method, at 150KN-pressure and $165^{\circ} \mathrm{C}$ - temperature, pre-heating time 2, $10 \mathrm{~min}$ and 10 min cooling with water.

\section{Characterization}

Polymer composite and nanocomposite samples have been tested physicomechanically (determining flow indexes area) and morpho-structurally (FT-IR and DSC).

- The Melt flow index- MFI was determined on a THERMO- HAAKE 2000 Melt Flow (Thermo Electron Corporation, Germania) at a temperature of $175^{\circ} \mathrm{C}$ and a 5 $\mathrm{kg}$ load, according to ISO 1133/2003. The maximum amount of material introduced is $6 \mathrm{~g}$.

-FT-IR spectrometry was done using a double-beam molecular absorption IR spectrometer, in the range of 4000 $600 \mathrm{~cm}^{-1}$, using the FT-IR Able J asco 4200 device equipped

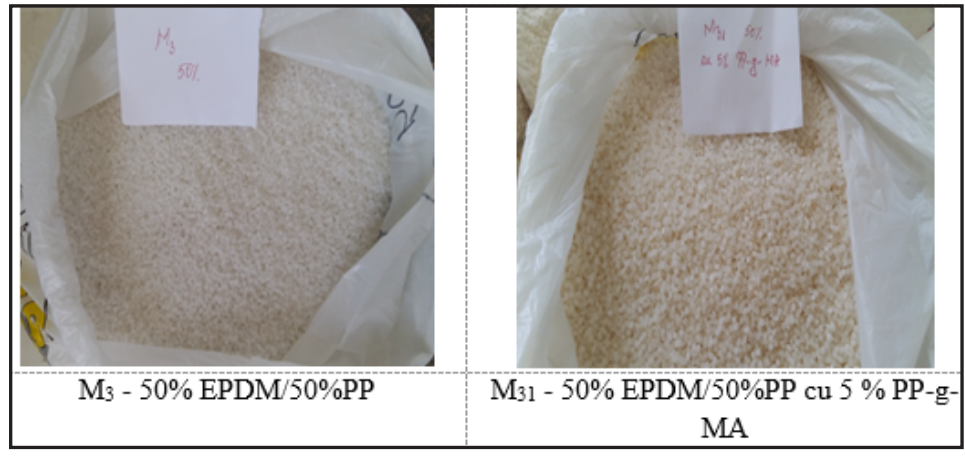

\begin{tabular}{|c|l|c|c|}
\hline No. & Technological parameter & UM & Values \\
\hline 1. & Temperature in: & ${ }^{\circ} \mathrm{C}$ & \\
& Area I & & $150-160$ \\
& Area II & & $160-165$ \\
& Area III & & $165-170$ \\
& Area IV & & $165-170$ \\
& Area V & & $170-175$ \\
& Area VI & & $170-175$ \\
& Area VII & & $165-170$ \\
& Area VIII & & $160-150$ \\
& Area IX & Rotmin. & $110-100$ \\
\hline 2. & Screw rotation speed & $150-280$ \\
\hline 3. & Screw-feed dispenser speed & Rot/min & $8,2-10$ \\
\hline 4. & Axial pressure & $\mathrm{KN}$ & $4,5-5,5$ \\
\hline 5. & Melt pressure & Bar & $50-60$ \\
\hline 6. & Melt temperature (nozzle) & ${ }^{\circ} \mathrm{C}$ & $150-175$ \\
\hline 7. & Intensity of power & $\mathrm{A}$ & 24 \\
\hline
\end{tabular}

Fig. 2. Mixtures of polymer composites obtained using the extruder granulator $\left(\mathrm{M}_{3}-50 \% \mathrm{EPDM} / 50 \% \mathrm{PP}\right.$ and 50\% EPDM/50\%PP with $5 \%$ PP-g-MA)
Table 2

TECHNOLOGICAL PARAMETERS OF DEVELOPING POLYMER COMPOSITES AND NANOCOMPOSITES 


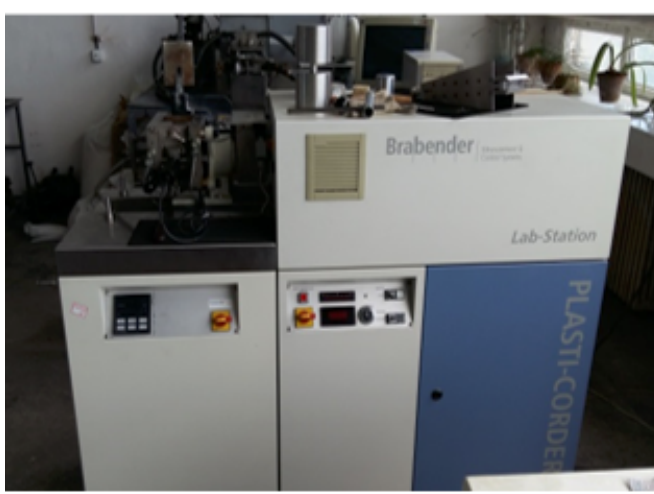

Detail - A

with ATR with diamond crystal and sapphire head, suitable for determinations on rigid and semi-rigid samples.

-Differential scanning calorimetry -DSC analysis was conducted using a Netzsch 449CSTA J upiter device. Measurements were made in a temperature range of 120 $190^{\circ} \mathrm{C}$, the area was measured in the temperature range of $130-180^{\circ} \mathrm{C}$. The basic material in which the other ingredients are dispersed is PP and thus tested samples were reported to differential scanning calorimetry (DSC) analysis of the plastomer - polypropylene.

\section{Results and discussions}

Melt Flow Index

Table 3 presents results of flow indexes of dynamically cured polymer composites and nanocomposites after conditioning for $24 \mathrm{~h}$ at the temperature of $20 \pm 2{ }^{\circ} \mathrm{C}$, according to the standard in force.

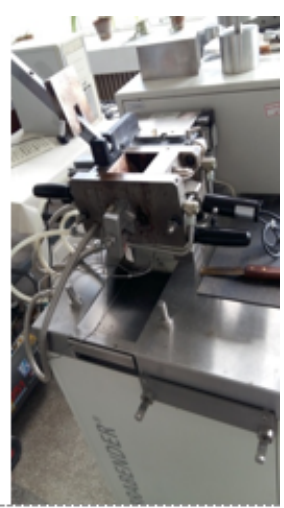

Detail - B
Fig. 3. Plasti-Corder Brabender Mixer $350 \mathrm{E}$ (a and b mixer details)
When adding 50\% EPDM elastomer and 50\% PP plastomer in equal proportions, flow index values decrease compared to the reference PP sample, due to increased melt viscosity. Melt viscosity was strongly influenced by the presence of the crosslinking and reinforcing agent therefore flow index values are slightly higher in the case of the polymer nanocomposites tested ( $M_{315} M_{1}, M_{315} M_{2^{\prime}}$ $\left.M_{315} M_{3}\right)$. We can thus affirm that polymer nanocomposites with low flow indexes may be processed only by pressing.

\section{FT-IR spectroscopy:}

Recorded FT-IR spectra, figures 4 and 5 , show the main absorption bands of polypropylene and EPDM rubber, as well as the assignment of their vibration bands: $1375 \mathrm{~cm}^{-1}$ - $\left(\mathrm{CH}_{2}\right)(\mathrm{CH}), 1455 \mathrm{~cm}^{-1}-\left(\mathrm{CH}_{2}\right)$ and $\left(\mathrm{CH}_{3}\right)$, at $1167 \mathrm{~cm}^{-1}$ the presence of the isopropyl group, and for EPDM rubber, absorption bands are the same as for dynamically cured polymer composites: $721.247 \mathrm{~cm}^{-1}$ - crystallinity $\mathrm{CH}_{2^{\prime}}$

Table 3

VALUES OF FLOW INDEXES FOR POLYMER COMPOSITES AND NANOCOMPOSITES BASED ON PP/PP-g-MA/EPDM/MMT/PD

\begin{tabular}{|c|c|c|c|c|c|c|c|c|}
\hline \multirow{2}{*}{ Work temperature } & \multirow{2}{*}{$\mathrm{UM}$} & & \multicolumn{5}{|c|}{ Sample code } \\
\cline { 3 - 9 } & & $\mathrm{PP}$ & $\mathrm{M}_{3}$ & $\mathrm{M}_{31}$ & $\mathrm{M}_{315}$ & $\mathrm{M}_{315} \mathrm{M}_{1}$ & $\mathrm{M}_{315} \mathrm{M}_{2}$ & $\mathrm{M}_{315} \mathrm{M}_{3}$ \\
\hline $\begin{array}{c}175^{\circ} \mathrm{C}, \text { SR ISO } \\
1133 / 2015\end{array}$ & $\mathrm{~g} / 10 \mathrm{~min}$ & 45 & 7.05 & 11.0 & 23.7 & 8.16 & 16.4 & 33.83 \\
\hline
\end{tabular}

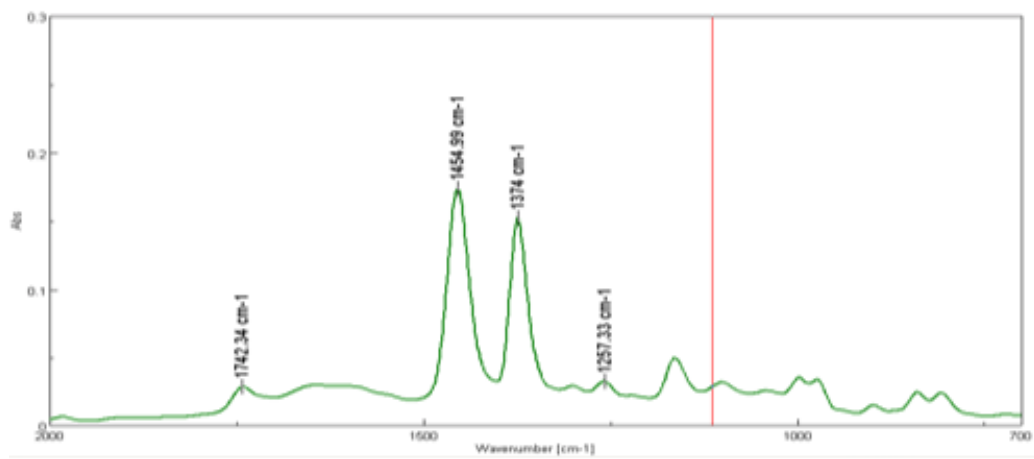

Fig. 4. FT-IR spectrum for PP

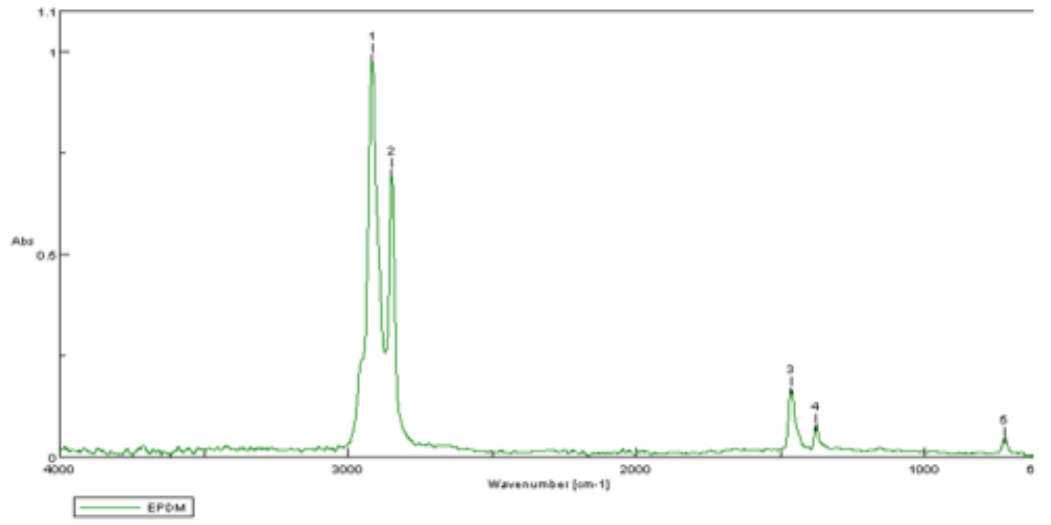

Fig. 5. FT-IR spectrum for EPDM rubber 


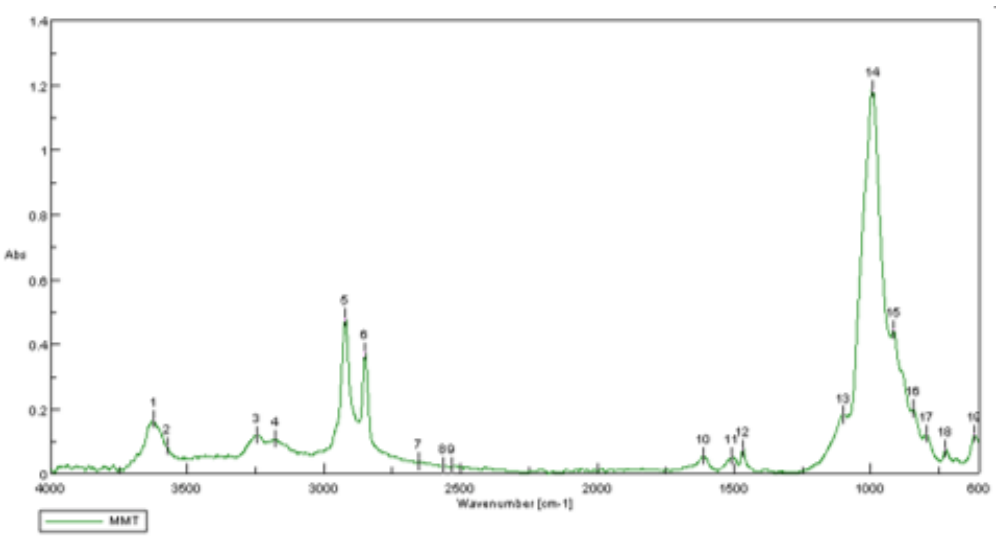

Fig. 6. FT-IR spectrum for MMT nanoparticles

\begin{tabular}{|l|l|l|l|}
\hline Sample code & Frequency & \multicolumn{1}{|c|}{ Intensity } & \multicolumn{1}{|c|}{ Vibration assignments } \\
\hline PP & 1455,74 & 0,178386 & $\left(\mathrm{CH}_{2}\right)$ and $\left(\mathrm{CH}_{3}\right)$ \\
& 1375,83 & 0,248779 & $\left(\mathrm{CH}_{2}\right)(\mathrm{CH})$ \\
& 1255,9 & 0,021153 & $\left(\mathrm{CH}_{2}\right)(\mathrm{CH})$ \\
& 1166,83 & 0,0409114 & Presence of isopropyl group \\
\hline EPDM & 1463,71 & 0,1755108 & $\left(\mathrm{CH}_{2}\right) \mathrm{CH}_{3}$ asymmetric \\
& 1375,96 & 0,0827913 & $\mathrm{CH}_{3}$ symmetric \\
& 721,247 & 0,0512599 & $\left(\mathrm{CH}_{2}\right)$ crystallinity \\
\hline $\mathrm{M}_{315 \mathrm{M}_{3}}$ & 1456,96 & 0,174604 & $\left(\mathrm{CH}_{2}\right)$ and $\left(\mathrm{CH}_{3}\right)$ \\
& 1375,96 & 0,136418 & $\mathrm{CH}_{3}$ symmetric \\
& 1261,22 & 0,116693 & $\left(\mathrm{C}-\mathrm{CH}_{3}\right)\left(\mathrm{CH}_{3}\right)$ \\
& 1089,58 & 0,167129 & $\left(\mathrm{CH}_{3}\right)\left(\mathrm{C}-\mathrm{CH}_{3}\right)$ \\
& 721,247 & 0,0202893 & $\left(\mathrm{CH}_{2}\right)$ crystallinity \\
\hline
\end{tabular}

$1375.9 \mathrm{~cm}^{-1}$-symmetric deformation $\mathrm{CH}_{3,} 1463,71 \mathrm{~cm}^{-1}$ shearing vibrations $\mathrm{CH}_{2}$ and $\mathrm{CH}_{3}$ asymmetric). Table 4 also indicates the frequency and assignment of vibration bands of the sample containing the maximum amount of chemically modified layered clay $\left(7 \%-\mathrm{M}_{315} \mathrm{M}_{3}\right)$.

The FT-IR spectrum recorded for montmorillonite, figure 6 , shows the bands of the aluminosilicate network, and the most intense is the band at $993.16 \mathrm{~cm}^{-1}$ (peak 14). Bands noticed at $3177.15 \mathrm{~cm}^{-1}$ (peak 3) and $3245.61 \mathrm{~cm}^{-1}$ (peak 4) are characteristic to vibration assignments for primary amines. Assignments of vibration bands at 795 $\mathrm{cm}^{-1}, 842.74 \mathrm{~cm}^{-1}$ and $916.022 \mathrm{~cm}^{-1}$ are characteristic to deformation bands involving hydroxyl ions. Bands at $2849.31 \mathrm{~cm}^{-1}$ (peak 5) and $2922.59 \mathrm{~cm}^{-1}$ (peak 6) indicate assignments of symmetric and asymmetric stretching vibrations of methylene groups.

\section{Differential scanning calorimetry - DSC:}

Differential scanning calorimetry (DSC) analysis shows an overall independent thermal behaviour of each component (fig. 7-9). The EPDM phase barely shows on the thermogram due to the lack of crystallinity and thus the melting process does not show compared to that of polypropylene. The presence of compatibilizer does not significantly influence the thermogram due to the low amount $(5 \%)$ and occurrence only at the interaction of PP/ EPDM interface. Differential scanning analysis data show

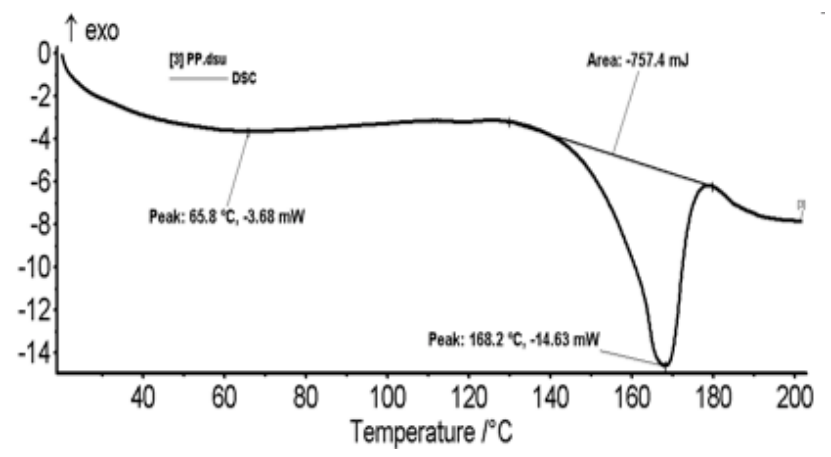

Fig. 7. DSC analysis of the PP sample

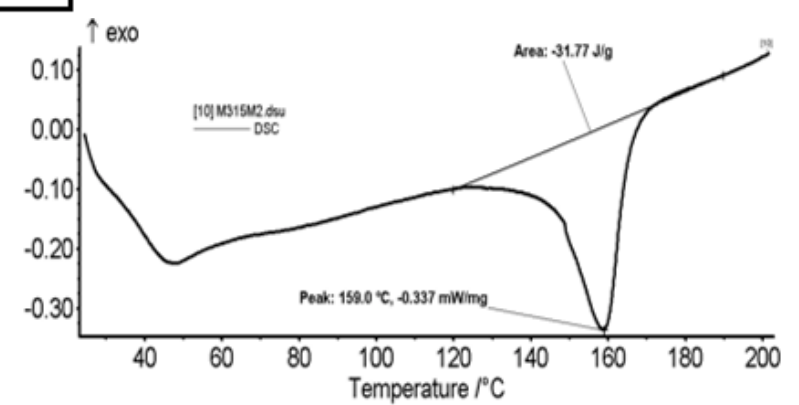

Fig. 8. DSC analysis of the $M_{315} M_{3}$ sample

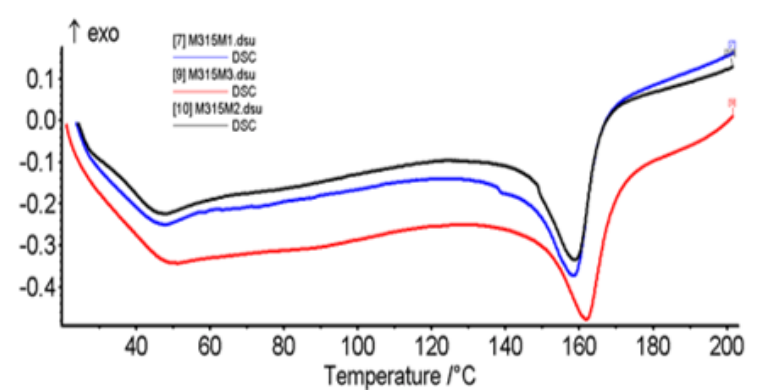

Fig. 9. DSC analysis of the $M_{315} M_{1^{\prime}} M_{315} M_{2}, M_{315} M_{3^{\prime}}$, sample the same aspect of mixtures containing DCP crosslinker and nanometric reinforcing agent -MMT $\left(M_{315} M_{1}, M_{315} M_{2}\right.$ $M_{315} M_{3}$ ) while at the same time one can see that temperatures decrease compared to PP sample, the material in which components are dispersed.

\section{Conclusions}

Polymer composites and nanocomposites based on dynamically cured PP/EPDM were prepared in two stages. In the first stage, thermoplastic olefins elastomers based on PP/EPDM, with and without PP-g-MA were obtained by melt mixing. In the second stage dynamically cured polymer nanocomposites reinforced with MMT nanoparticles and crosslinked with DCP were obtained. Flow indexes were determined according to standards in force after conditioning at room temperature for 24 hours, 
establishing thus that mixtures with low flow indexes may be processed only by pressing and extrusion. Differential scanning analysis shows the same aspect of mixtures containing DCP crosslinker and nanometric reinforcing agent, and the relatively low presence of PP-g-MA does not significantly influence recorded thermograms. Recorded FT-IR spectra show the main absorption bands of polypropylene and EPDM rubber, as well as the assignments of their vibration bands, and also that polypropylene is the material in which the other elements are dispersed, as is confirmed by the presence of characteristic peaks.

Dynamically cured polymer composites and nanocomposites compatibilized and reinforced show potential applications in the footwear industry, as well as in the consumer goods industry.

Acknowledgements: This research was financed through PN 09-10 02 27/2014 project: New polymeric alloys compounded with nanoparticles for footwear industry; supported by Romanian Ministry of Education.

\section{References}

1. MISCA, B.R.H., Polimeric composites materials, Cluj Napoca, ed. Presa Universitara Clujeana, 2000.

2. UTRACKI, L. A., Comercial Polymer Blends, ed. Chapman \& Hall, London, 1998.

3. MIRCI, L.E., Thermoplastic Elastomers, ED. Art. Press \& Ed. Augusta, Timisoara, 2005.

4. VOLINTIRU, T., IVAN, GH., Technological bases of processing elastomers, ed. Tehnica, Bucuresti, 1974.

5. FISHER, WK, Thermoplastic blends of partially cured monoolefinic copolymer rubber and polyolefin plastic, US Patent 3. 862. 106, 1975. 6. CORAN, AY, PATEL, RP, Rubber-thermoplastic compositions part I: EPDM-polypropylene thermoplastic vulcanizates, Rubber Chem Technol, 53, 1980, p. 141.

7.STELESCU, M. D., Thermoplastic elastomers based on ethylenepropolena rubber (EPDM), which can be used in the footw ear industry, ed. Performantica, lasi, ISBN: 978-973-730-809-2, 2011.

8. NITUICA, M., MEGHEA, A., SONMEZ, M., ALEXANDRESCU, L., GURAU, D., GEORGESCU, M., in Proceedings of 5ht International Conference of Advanced Materials and Systems - ICAMS, 2014, ed. CERTEX, Bucuresti ISSN: 2068-0783, p. 103.
9. STELESCU, M. D, NICULESCU-ARONI-G, MANAILA, E., Processing and Statistical Analysis of the Experimental Data Resulted from EPDM Rubber Grafting and Crosslinking with Accelerated Electrons in the Presence of TMPT, Mat. Plast., 46, no. 1, 2009, p. 48.

10. PEYMAN EZZATI, ISMAEIL GHASEMI, MOHAMMAD KARRABI, HAMED AZIZI, Reological Behaviour of PP/EPDM Blend: The Effect of Compatibilization, Iranian Polymer Journal, 9, 17, 2008, p. 670.

11. KARIM SHELESH-NEZHAD, HAMED ORANG and MAHDI MOTALLEBI Crystallization, shrinkage and mechanical characteristics of polypropylene/ $\mathrm{CaCO}_{3}$ nanocomposites, Journal of Thermoplastic Composite Materials, 26, 4, 2013, p. 544.

12.PFAENDNER R., Nanocomposites: Industrial opportunity or challenge?,Polymer Degradation and Stability, 95, 3, 2010, p. 369.

13.STELESCU, M.D., MANAILA, E., CRACIUN, G., J ournal of Applied Polymer Science, 128, 4, 2013, p. 2325.

14. STELESCU, M. D, AIRINEI, A, HOMOCIANU, M., TIMPU, D., GRIGIRA C., Characterization of Some EPDM-g-MA/OMMT Nanocomposites, Mat. Plast., 47, no. 4, 2010, p. 411.

15. NASKAR, K., Dynamically vulcanized PP/EPDM thermoplastic elastomers, Ph. D. Thesis, University of Kunstst., 2004.

16. JINESCU, V.C, TEODORESCU, N., Extruder Performance based on a Correlated Extruder Head-screw-barrel Unit Working Field, Mat. Plast., 52, 1, 2015, p. 1.

17. NITUICA (VILSAN), M., MEGHEA, A., ALEXANDRESCU, L, TRUSCA, R., OPREA, O., Dynamically cured polymer composite based on PP and EPDM for footwear industy, Leather and Footwear J ournal, seria B, 15, 2, 2015, p. 95.

18. NITUICA (VILSAN), M., GURAU, D., TRUSCA, R., Polymer structures based on dynamically cured plastomer/elastomer, Mat. Plast., 53, no. 3, 2016, p. 424

19. NIUTICA (VILSAN), M., MEGHEA, A., SONMEZ, M., GEORGESCU, $M$. . Dynamically cured hybrid polymer nanocomposite based on polypropylene and EPDM rubber, U.P.B. Scientific Bulletin, seria B, 77, 3, 2015, p. 165.

20.ALEXENDRESCU, L., SONMEZ, M., JUGANARU, M., JUGANARU, B., Structuri polimerice pe baza de cauciuc cloroprenic si butadien-coacrilonitril pentru talpi vulcanizate, utilizate în medii de lucru cu risc termic, Brevet de inventie nr. RO 129558, 2012.

Manuscript received: 26.05 .2018 